\title{
Protein Synthesis in Hepatocytes Isolated from Patients with Gastrointestinal Malignancy
}

\author{
H. Fletcher Starnes, Jr., Robert S. Warren, and Murray F. Brennan \\ Memorial Sloan-Kettering Cancer Center, New York, New York 10021
}

\section{Abstract}

To investigate the effect of remote and proximate cancer on hepatic protein metabolism, we determined rates of total protein synthesis by hepatocytes (HPS) isolated from 31 patients undergoing liver wedge biopsy: 7 patients with benign disease, 14 with gastric cancer, and 10 with colorectal cancer (5 of whom had liver metastases).

Patients with malignant disease without weight loss had a threefold higher rate of total HPS $\left(4,980 \pm 814 \mathrm{pmol} / \mathrm{h}\right.$ per $10^{5}$ viable cells) than patients with benign disease without weight loss $\left(1,278 \pm 318 \mathrm{pmol} / \mathrm{h}\right.$ per $10^{5}$ viable cells, $\left.P<0.001\right)$. Among the patients with gastric cancer, eight with preoperative weight loss had lower rates of HPS $(380 \pm 90 \mathrm{pmol} / \mathrm{h}$ per $10^{5}$ viable cells) than those without weight loss $(4,061 \pm 401$ pmol/h per $10^{5}$ viable cells, $P<0.002$ ). The highest rates of HPS were seen in patients with colorectal cancer with liver metastases $\left(8,005 \pm 1,975 \mathrm{pmol} / \mathrm{h}\right.$ per $10^{5}$ viable cells) vs. colorectal cancer patients without liver metastases $(3,060 \pm 575$ $\mathrm{pmol} / \mathrm{h}$ per $10^{5}$ viable cells, $\left.P<0.03\right)$. These data indicate that modulation of hepatic protein synthesis occurs in malignancy in man. However, the stimulatory influence of the tumor-bearing state may be overridden by the inhibitory effects of cachexia.

\section{Introduction}

Alterations of protein metabolism have been demonstrated in the presence of malignancy. Most studies have found higher rates of whole body protein metabolism in cancer patients compared with patients with benign disease when appropriately controlled for nutritional status and weight loss (1-6). Because the liver plays a central role in control of intermediary metabolism, we believed it would be important to examine the in vitro hepatic contribution to the higher whole body protein flux found with in vivo studies of patients with cancer. Studies in animal models of malignancy have shown conflicting results in measuring the effects of cancer on hepatic protein synthesis (7-10), and only one previous study has been able to address this question directly in man (11).

A technique for obtaining a viable suspension of isolated hepatocytes from adult rat liver was originally introduced by Berry and Friend (12) and modified by Seglen (13). Bourel et

Address reprint requests to H. Fletcher Starnes, Jr., M.D., Stanford University Medical Center, SO67, Stanford, CA 94305.

Received for publication 3 November 1986 and in revised form 22 June 1987.

J. Clin. Invest.

(c) The American Society for Clinical Investigation, Inc.

$0021-9738 / 87 / 11 / 1384 / 07 \quad \$ 2.00$

Volume 80, November 1987, 1384-1390 al. (14) had isolated human hepatocytes from needle biopsy specimens and Strom et al. (15) showed that the collagenase perfusion technique could be applied to human liver obtainable from surgical procedures.

The present investigation was undertaken to examine the relative contribution of malignancy and nutritional status to hepatic protein synthesis in man. Rates of total protein synthesis were studied in hepatocytes isolated from patients with a variety of malignancies and differing antecedent nutritional status.

\section{Methods}

Patients. 31 patients were studied; 15 male and 16 female, ranging in age from 29 to $79 \mathrm{yr}$ with a mean of $56.5 \pm 3 \mathrm{yr}$. Table I lists the pathological diagnoses for patients with malignant and benign disease. Table II provides information on the extent of disease in the patients studied: histological lymph node involvement and presence of metastatic disease. We excluded patients with diabetes, sepsis, and those receiving nutritional support because of the metabolic changes known to occur in these states. All patients were evaluated and treated at Memorial Sloan-Kettering Cancer Center (MSKCC). The protocol followed for obtaining human specimens was approved by the MSKCC Institutional Review Board, although all patients with malignancy were undergoing liver biopsy for staging or diagnosis.

A dietary history was obtained from each patient. An index of nutritional status was taken as the percent body weight loss upon admission to hospital (one minus the actual body weight on admission divided by the usual weight before illness). The serum albumin and total protein levels taken preoperatively are given in Table II.

The patients, fasted for $8-10 \mathrm{~h}$ before the operation, were premedicated with meperidine ( $50-75 \mathrm{mg}$ i.m.), hydroxyzine (50-75 mg i.m.), and glycopyrrolate $(0.2 \mathrm{mg}$ i.m.) and administered anesthetic agents as combinations of nitrous oxide, narcotic, or the inhalational agent isoflurane. Blood samples were taken just after anesthesia began and analyzed for the acute phase protein, C-reactive protein (CRP) by radial immunodiffusion (Calbiochem, Behring Diagnostic, La Jolla, CA), insulin, glucagon, and cortisol by radioimmunoassay (insulin and cortisol kits from Diagnostic Products, Inc., Los Angeles, CA, and glucagon kits from Cambridge Medical Diagnostics, Billerica, MA), serum albumin and total protein using computerized sequential multiple analysis equipment (Technicon Instruments Co, Tarrytown, NY), and lactate dehydrogenase (LDH) levels were determined spectrophotometrically using a centrifugal chemical analyzer (Multistat Plus, Instrumentation Laboratories, Lexington, MA).

Hepatocyte isolation. Liver wedge biopsies (2-7 g) were obtained soon after the abdominal cavity was opened. Areas of liver without metastases were biopsied and separate specimens were sent for formal histological examination. The orifices of all hepatic vessels in the liver biopsy were immediately flushed with ice-cold electrolyte solution for kidney preservation (Travenol Laboratories, Deerfield, IL) with $30 \mathrm{~g}$ added dextrose per liter. This procedure removed clots from the vessels to facilitate the perfusion. The specimen was then transported to the laboratory in the same solution.

1. Abbreviations used in this paper: CRP, C-reactive protein; LDH, lactate dehydrogenase; TNF, tumor necrosis factor. 
Table I.

Gastric cancer or gastric lymphoma

Weight-losing

Non-weight-losing

8

Colorectal cancer (non-weight-losing)

With liver metastases

Without liver metastases

Total

Benign disease (non-weight-losing)

Cholelithiasis, chronic cholecystitis

Nonfunctioning adrenal cortical adenoma

Esophageal duplication cyst

Total

Combined total

A two-step method of collagenase perfusion (14) was used for hepatocyte isolation. Plastic polyethylene catheters (18- and 20-gauge) were inserted into three to six vascular orifices on the cut surface of the liver specimen. A 45-60-min perfusion with calcium-free buffer was performed at $37^{\circ} \mathrm{C}$ at a flow rate of $10 \mathrm{ml} / \mathrm{min}$ per catheter. Calciumfree buffer was prepared as $145 \mathrm{mM} \mathrm{NaCl}, 7 \mathrm{mM} \mathrm{KCl}$, and $10 \mathrm{mM}$ Hepes from Boehringer Mannheim Biochemicals, Indianapolis, IN, to which $4 \mathrm{mM}$ dextrose and $0.25 \%$ bovine serum albumin was added (pH 7.4). This perfusion was followed by a 60 -min collagenase perfusion at $37^{\circ} \mathrm{C}$ with $0.5 \mathrm{mg}$ collagenase per $\mathrm{ml}$ (Lot No. 4196 from Cooper Biomedical, formerly Worthington Biochemical Corp, Freehold, NJ). Collagenase was added to a solution ( $\mathrm{pH} \mathrm{7.4)} \mathrm{of} 70 \mathrm{mM}$ $\mathrm{NaCl}, 7 \mathrm{mM} \mathrm{KCl}, 6 \mathrm{mM} \mathrm{CaCl}$, and $100 \mathrm{mM}$ Hepes, to which $5 \mathrm{mM}$ dextrose and $0.25 \%$ bovine serum albumin (BSA) had been added.

Isolated hepatocytes were preincubated for $30 \mathrm{~min}$ in suspension buffer (Krebs-Ringer bicarbonate buffer with $1 \% \mathrm{BSA}$ at $\mathrm{pH}$ 7.4). Krebs-Ringer bicarbonate buffer was prepared as $118 \mathrm{mM} \mathrm{NaCl}, 5$ $\mathrm{mM} \mathrm{KCl}, 1.2 \mathrm{mM} \mathrm{MgSO}_{4}, 1.2 \mathrm{mM} \mathrm{KH}_{2} \mathrm{PO}_{4}, 12.5 \mathrm{mM} \mathrm{NaHCO}_{3}, 3.3$ $\mathrm{mM} \mathrm{CaCl}, 30 \mathrm{mM}$ Hepes, and $30 \mathrm{mM}$ Tris (hydroxymethyl) methylaminoethanosulfonic acid from Sigma Chemical Co., St. Louis, MO. The cells were then sedimented by centrifugation at $50 \mathrm{~g}$ for $4 \mathrm{~min}$ at room temperature, the supernatant discarded, and the hepatocytes resuspended in incubation medium, described in the next section.
With this procedure, viability, assessed by trypan blue exclusion for all 31 patients studied, was $65 \pm 2 \%$ before incubation. In parallel experiments, viability of human hepatocytes in an additional nine patients was assessed by trypan blue exclusion as well as by measurement of cytoplasmic enzyme leakage (LDH release) (16). The fraction of cellular LDH released into the supernatant of the incubation media was determined and found to be $2.1 \pm 0.4 \%$ over $60 \mathrm{~min}$ in nine patients. Between 2 and $50 \times 10^{6}$ cells were isolated per biopsy specimen and the mean total yield was $17 \pm 2 \times 10^{6}$ cells per specimen.

Measurement of valine incorporation into proteins. Total cellular and secreted protein synthesis during $1 \mathrm{~h}$ was assayed as $U-{ }^{14} \mathrm{C}$-valine incorporation into TCA-insoluble material, as previously described (10). The assay was initiated by the addition of the cells to an incubation mixture at $37^{\circ} \mathrm{C}$ containing $\mathrm{U}-{ }^{14} \mathrm{C}$-valine $(5 \mathrm{mM}, 0.4 \mu \mathrm{Ci} / \mu \mathrm{mol})$, sodium pyruvate $(20 \mathrm{mM})$ as an energy source, and 19 amino acids at physiological concentrations, giving a final volume of $3.03 \mathrm{ml}$. The mean cell count for the assay was $3.0 \pm 0.4 \times 10^{6}$ cells $/ \mathrm{ml}$.

Aliquots of cells and medium were removed at timed intervals of 0 , 30 , and $60 \mathrm{~min}$; TCA was added to a final concentration of $5 \% \mathrm{wt} / \mathrm{vol}$. The precipitates were stored at $4^{\circ} \mathrm{C}$ for over $1 \mathrm{~h}$, then collected on 0.45 $\mu \mathrm{M}$ nitrocellulose filters and washed copiously with ice-cold 5\% TCA, and counted in $10 \mathrm{ml}$ Biofluor (New England Nuclear, Boston, MA) using a Tricarb liquid scintillation counter (Packard Instrument Co., Inc., Downers Grove, IL). Internal standards were used for counting efficiency calculations.

Rates of incorporation of radioactivity into TCA-precipitable material (dpm/h per $10^{5}$ viable cells) were divided by the specific activity of valine in the incubation medium to determine the amount of valine incorporated. In this technique of using high concentrations of valine, extracellular, intracellular, and amino-acylated transfer RNA pools have been shown to equilibrate rapidly and the extracellular specific radioactivity can be used as the immediate protein precursor pool specific activity (17).

Statistics. All data were presented as the mean \pm SE. Statistical comparisons were made using the nonparametric Kruskal-Wallis test. Significance, in all cases, was designated at the $5 \%$ level. Linear regression analysis was performed by the method of least squares (18).

\section{Results}

Valine was incorporated into TCA-insoluble material by isolated hepatocytes from liver biopsy specimens in a linear fashion over $60 \mathrm{~min}$. The mean hepatocyte viability, as assessed by

Table II.

\begin{tabular}{|c|c|c|c|c|c|}
\hline & Primary site & $\begin{array}{l}\text { Histological lymph } \\
\text { node involvement }\end{array}$ & $\begin{array}{l}\text { Metastatic } \\
\text { disease }\end{array}$ & $\begin{array}{l}\text { Serum } \\
\text { albumin pre-op }\end{array}$ & Total protein pre-op \\
\hline & & & & $g / d l$ & $g / d l$ \\
\hline \multicolumn{6}{|l|}{ Gastric cancer } \\
\hline Weight-losing $(n=8)$ & $\begin{array}{l}3 \text { proximal stomach } \\
5 \text { distal stomach }\end{array}$ & $4 / 8$ & $0 / 8$ & $3.8 \pm 0.2(7)$ & $5.9 \pm 0.4(6)$ \\
\hline Non-weight-losing $(n=6)$ & $\begin{array}{l}3 \text { proximal stomach } \\
3 \text { distal stomach }\end{array}$ & $5 / 6$ & $0 / 6$ & $4.2 \pm 0.2(6)$ & $6.5 \pm 0.2(6)$ \\
\hline \multicolumn{6}{|l|}{ Colorectal cancer } \\
\hline Without liver metastases $(n=5)$ & $\begin{array}{l}4 \text { rectosigmoid } \\
1 \text { right colon }\end{array}$ & $2 / 5$ & $0 / 5$ & $4.0 \pm 0.1(5)$ & $6.9 \pm 0.1(5)$ \\
\hline With liver metastases $(n=5)$ & $\begin{array}{l}2 \text { rectosigmoid } \\
2 \text { right colon } \\
1 \text { left colon }\end{array}$ & $5 / 5$ & $5 / 5$ & $4.3 \pm 0.2(5)$ & $7.0 \pm 0.2(5)$ \\
\hline Benign disease $(n=7)$ & See Table I & $0 / 7$ & $0 / 7$ & $4.4 \pm 0.1(7)$ & $7.1 \pm 0.2(7)$ \\
\hline
\end{tabular}

Number of patients in parentheses. 


\begin{tabular}{|c|c|c|c|c|c|}
\hline & $\mathbf{n}$ & $\begin{array}{l}\text { Viability before } \\
\text { incubation }\end{array}$ & $\begin{array}{l}\text { Viability at } 60 \mathrm{~min} \\
\text { of incubation }\end{array}$ & Mean cell count & Mean total yield \\
\hline & & $\%$ & $\%$ & $\times 10^{6}$ & $\times 10^{6}$ \\
\hline \multicolumn{6}{|l|}{ Gastric cancer } \\
\hline Weight-losing & 8 & $69 \pm 4$ & $65 \pm 5$ & $3.3 \pm 0.7$ & $29.7 \pm 3.2$ \\
\hline Non-weight-losing & 6 & $64 \pm 7$ & $61 \pm 5$ & $3.1 \pm 1.4$ & $19.5 \pm 6.6$ \\
\hline \multicolumn{6}{|l|}{ Colorectal cancer } \\
\hline Without liver metastases & 5 & $55 \pm 2$ & $55 \pm 3$ & $1.6 \pm 0.3$ & $12.3 \pm 3.2$ \\
\hline With liver metastases & 5 & $66 \pm 6$ & $64 \pm 4$ & $3.7 \pm 1.2$ & $17.2 \pm 4.4$ \\
\hline Benign disease & 7 & $67 \pm 4$ & $62 \pm 5$ & $1.9 \pm 0.4$ & $10.9 \pm 2.9$ \\
\hline
\end{tabular}

trypan blue exclusion in all 31 patients studied, was $65 \pm 2 \%$ at the onset of incubation and $62 \pm 2 \%$ at $60 \mathrm{~min}$ of incubation. Table III contains information on the viability, mean cell count, and total yield of hepatocytes in the different groups of patients studied.

To determine if there were differences in rates of synthesis of total hepatocyte protein between benign and malignant disease, patients matched for nutritional status were examined (Fig. 1). 16 patients with gastrointestinal malignancies with histories of no antecedent weight loss had a mean hepatocyte protein synthesis rate of $4,980 \pm 814 \mathrm{pmol} / \mathrm{h}$ per $10^{5}$ viable cells. Seven patients undergoing laparotomy for benign disease had a mean rate of hepatic protein synthesis of $1,278 \pm 318$ pmol/h per $10^{5}$ viable cells $(P<0.001)$. Hence, a threefold higher rate of total hepatocyte protein synthesis was found in patients with malignant disease without weight loss compared with that seen in patients with benign disease without weight loss.

Fig. 2 details total hepatocyte protein synthesis rates from gastric cancer patients as a function of their percent body weight losses. 12 patients with gastric or gastroesophageal junction adenocarcinoma were studied, and two patients had primary gastric lymphoma. There was a 10 -fold higher rate of protein synthesis by hepatocytes from patients with no nutritional deficit and without weight loss compared with that seen in patients with weight loss $\left(4,061 \pm 401 \mathrm{pmol} / \mathrm{h}\right.$ per $10^{5}$ viable

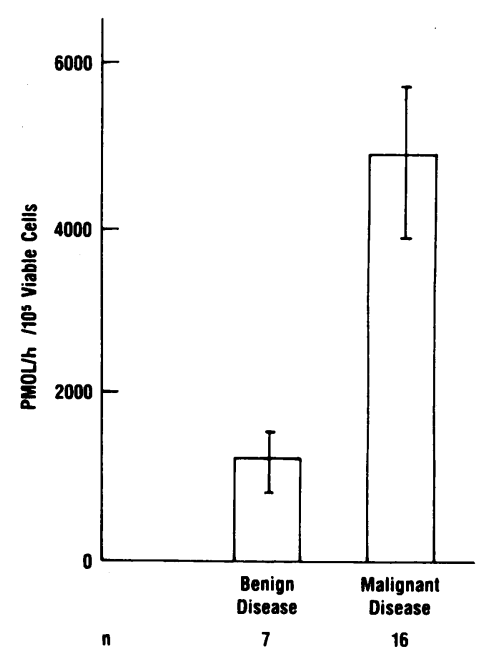

Figure 1. Total ${ }^{14} \mathrm{C}$-valine incorporation into protein in hepatocytes isolated from patients with benign and malignant disease without weight loss. Data given as means \pm SE. Seven patients with benign disease had a mean rate of hepatic protein synthesis of $1,278 \pm 318 \mathrm{pmol} / \mathrm{h}$ per $10^{5}$ viable cells. 16 patients with gastrointestinal malignancies had a mean hepatocyte protein synthesis rate of $4,980 \pm 814 \mathrm{pmol} / \mathrm{h}$ per $10^{5}$ viable cells (chisquare by Kruskal Wallis nonparametric test, 12.07; d.f. $=1 ; P<0.001)$. cells) for gastric malignancy without weight loss compared with $380 \pm 90 \mathrm{pmol} / \mathrm{h}$ per $10^{5}$ viable cells for gastric cancer patients with weight loss $(P<0.002)$. Poor nutritional status is associated with decreased hepatocyte protein synthesis. A minimal rate of hepatic protein synthesis appeared to be reached in patients with $>5 \%$ body weight loss. The weightlosing gastric cancer patients had somewhat lower mean preoperative serum albumin and total protein levels than gastric cancer patients without weight loss $(3.8 \pm 0.2$ vs. $4.2 \pm 0.2 \mathrm{~g} / \mathrm{dl}$, respectively). However, this difference did not reach statistical significance. The two gastric lymphoma patients with weight loss had rates of hepatocyte protein synthesis near the median rate found for gastric cancer patients with weight loss. Patients with benign disease without weight loss had a threefold lower rate of total hepatocyte protein synthesis compared with gastric cancer patients without weight loss $(1,278 \pm 318 \mathrm{pmol} / \mathrm{h}$ per $10^{5}$ viable cells vs. $4,061 \pm 401 \mathrm{pmol} / \mathrm{h}$ per $10^{5}$ viable cells, respectively, $P<0.001$ ).

Patients with a different tumor type and with and without metastatic disease were also investigated. Protein synthesis by hepatocytes isolated from patients with primary colorectal carcinoma (without weight loss) was significantly increased over that in patients with benign disease (Fig. 3). Patients with colorectal cancer with metastases in liver had elevated hepatocyte protein synthesis rates $\left(8,005 \pm 1,975 \mathrm{pmol} / \mathrm{h}\right.$ per $10^{5}$ viable cells) compared with colorectal cancer patients without liver metastases $\left(3,060 \pm 575 \mathrm{pmol} / \mathrm{h}\right.$ per $10^{5}$ viable cells, $P$ $<0.03$ ). Liver biopsies were taken in each case from areas of liver free of tumor, both on gross examination and microscopically. One rectal cancer patient had primary rectal lymphoma.

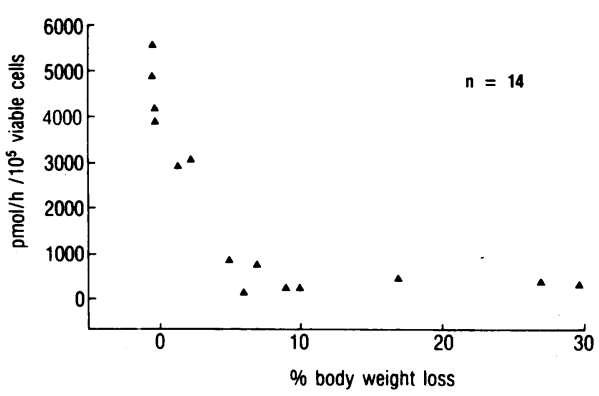

Figure 2. Total ${ }^{14} \mathrm{C}$-valine incorporation into protein in hepatocytes from gastric cancer patients as a function of their percent body weight losses. Poor nutritional states are associated with decreased hepatocyte protein synthesis. Data shown as means \pm SE. 


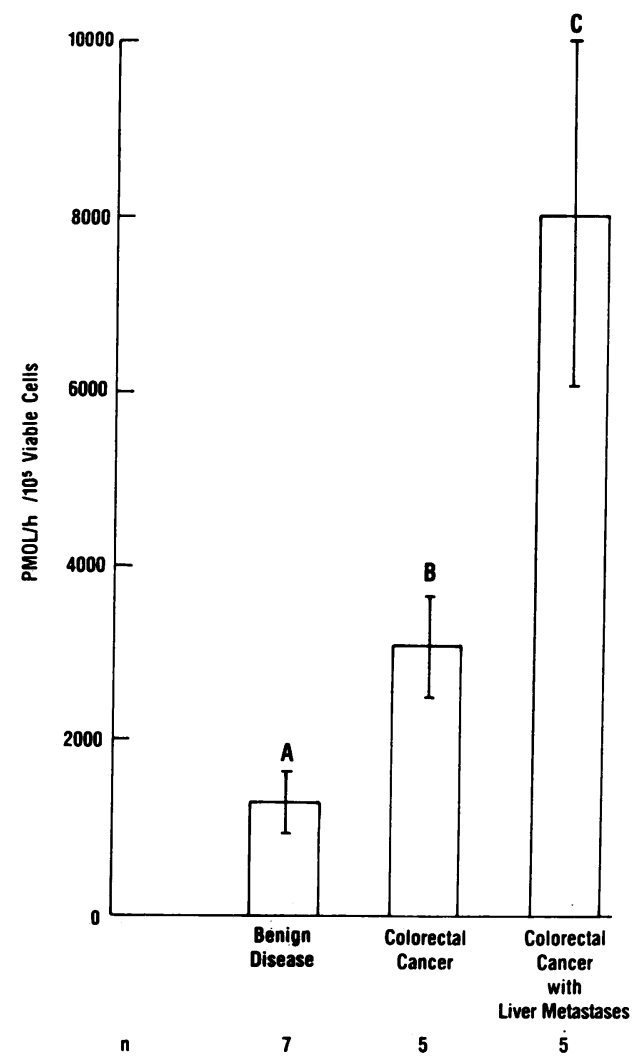

Figure 3. Total ${ }^{14} \mathrm{C}$-valine incorporation into protein in hepatocytes from patients with benign disease $(A)$, patients with colorectal cancer without liver metastases $(B)$, and colorectal cancer patients with liver metastases $(C)$. Patients with colorectal cancer with metastases in liver had elevated hepatocyte protein synthesis rates $(8,005 \pm 1,975$ $\mathrm{pmol} / \mathrm{h}$ per $10^{5}$ viable cells) compared with colorectal cancer patients without liver metastases $\left(3,060 \pm 575 \mathrm{pmol} / \mathrm{h}\right.$ per $10^{5}$ viable cells; chisquare by Kruskal Wallis nonparametric test, 4.8 ; d.f. $=1 ; P<0.03$ )

This patient's rate of hepatocyte protein synthesis was the median for the patients with colorectal cancer without liver metastases.

Differences in hepatocyte protein synthesis associated with malignancy and diminished nutritional status cannot be explained by differences in anesthetic agents administered or in age in the varying groups. 24 of the 31 patients studied received the same anesthetic agents: mixed nitrous oxide, narcotic, and isoflurane. Four weight-losing gastric cancer patients had mixed nitrous oxide and narcotic without isoflurane, but the mean hepatocyte protein synthesis rate for these patients was not significantly different from that for four weight-losing gastric cancer patients who recieved mixed nitrous oxide, narcotic, and isoflurane $\left(487 \pm 169 \mathrm{pmol}\right.$ h per $10^{5}$ viable cells vs. $274 \pm 35 \mathrm{pmol} / \mathrm{h}$ per $10^{5}$ viable cells, respectively). One patient with benign disease was administered nitrous oxide and isoflurane, the remaining five patients with benign disease had mixed nitrous oxide, narcotic, and isoflurane. One patient with colorectal cancer with liver metastases had nitrous oxide and narcotic. All the remaining patients received the same anesthetic agents. Ages of the patients did not correlate with rates of hepatocyte protein synthesis ( $r$ $=-0.06$ by linear regression). Seven patients with benign disease had mean age $52 \pm 6$ yr and this was not significantly different from those 16 non-weight-losing malignant disease patients $(61 \pm 3 \mathrm{yr})$.
The alterations in protein synthesis in hepatocytes from patients in differing nutritional states with and without malignancy are unlikely to be explained by differences in viability, cell count, or yield in the different patient groups examined. As shown in Table III, we did find that hepatocytes from patients with colorectal cancer without liver metastases had somewhat lower viability, as assessed by trypan blue exclusion, than those patients with colorectal cancer who had liver metastases. However, this difference was not statistically significant, nor were any other statistically significant differences found among the varying groups of patients in cell viability as determined by trypan blue exclusion in all 31 patients. In parallel experiments, cell viability as measured as fraction of $\mathrm{LDH}$ released from hepatocytes over $1 \mathrm{~h}$ was found to be $1.9 \pm 0.6 \%$ in six patients with malignancy and three patients with benign disease had an $\mathrm{LDH}$ release of $2.3 \pm 0.4 \%$. No significant differences in either trypan blue exclusion or LDH release were found in hepatocytes from the patients with benign disease as compared with those with malignancy. Both the mean cell count used in the assay and the total yield of hepatocytes were somewhat lower in patients with benign disease, but this was not a statistically significant difference.

Levels of CRP in plasma taken simultaneously with the liver wedge biopsies were higher in non-weight-losing cancer patients than in patients with benign disease and equivalent nutritional status, although this difference did not reach statistical significance (Table IV). No differences were seen between weight-losing and non-weight-losing gastric cancer patients. The highest levels of CRP were found in patients with colorectal cancer metastatic to the liver. Patients with colorectal cancer with hepatic metastases had significantly higher plasma levels of CRP than patients with colorectal cancer without liver metastases $(P<0.05)$.

Serum and plasma hormone levels are also shown in Table IV. Neither serum insulin nor plasma glucagon levels were found to be correlated with rates of hepatocyte protein synthesis ( $r=-0.07$ and $r=0.20$, respectively by linear regression). In patients with equivalent nutritional status, plasma cortisol levels were elevated in the patients with malignancies $(22.6 \pm 1.9 \mathrm{mg} / \mathrm{dl})$ when compared with patients with benign disease $(13.3 \pm 2.8 \mathrm{mg} / \mathrm{dl} ; P<0.02)$. No differences were found between the group of patients with malignancies without weight loss and the group with benign disease with respect to the time of day that the serum was collected for the cortisol levels.

\section{Discussion}

Studies of whole-body metabolism in man have shown abnormalities in states of malnutrition and malignancy. Although reports of whole-body protein metabolism have shown conflicting results, many studies have found higher rates of whole-body protein turnover, synthesis, and catabolism in cancer patients when compared with patients with benign disease appropriately matched as to nutritional status, weight loss, and age (1-6). Clinically malnourished or starvationadapted normal subjects generally have been found to have low rates of whole-body protein turnover $(1,19)$.

It was our goal to develop a technique for assessing the contribution of the liver to these metabolic changes shown on the whole-body level in malnutrition and malignancy in man. The present report demonstrates that significant numbers of 


\begin{tabular}{|c|c|c|c|c|}
\hline & Serum insulin & Plasma glucagon & Plasma cortisol & CRP \\
\hline & $(\mu U / m l)$ & $(p g / m l)$ & $(\mu g / d l)$ & $(m g / d l)$ \\
\hline \multicolumn{5}{|l|}{ Gastric cancer } \\
\hline Weight-losing & $9.1 \pm 3.0(4)$ & $34 \pm 14(3)$ & $21.7 \pm 7.8(3)$ & $1.3 \pm 0.6(6)$ \\
\hline Non-weight-losing & $5.3 \pm 0.7(6)$ & $41 \pm 7(6)$ & $20.1 \pm 2.2(6)^{*}$ & $1.2 \pm 0.4(6)$ \\
\hline \multicolumn{5}{|l|}{ Colorectal cancer } \\
\hline Without liver metastases & $6.0 \pm 0.3(3)$ & $68 \pm 3(3)$ & $20.7 \pm 0.9(3)^{*}$ & $0.7 \pm 0.3(5)^{\ddagger}$ \\
\hline With liver metastases & $7.4 \pm 0.9(5)$ & $78 \pm 26(5)$ & $25.6 \pm 4.2(5)^{*}$ & $2.2 \pm 0.4(5)^{\ddagger}$ \\
\hline Benign disease & $6.4 \pm 2.4(4)$ & $100 \pm 13(4)$ & $13.3 \pm 2.8(4)^{*}$ & $0.6 \pm 0.6(5)$ \\
\hline
\end{tabular}

No. of patients who had samples obtained in parentheses. ${ }^{*}$ Chi-square by Kruskal Wallis, $5.31 ;$ d.f., $1 ; P<0.02$, for benign disease vs. malignant disease without weight loss. ${ }^{\ddagger}$ Chi-square by Kruskal Walis, 3.78; d.f., $1 ; P<0.05$, for colorectal cancer without liver metastases vs. colorectal cancer with liver metastases.

viable hepatocytes can be isolated from human liver biopsies and used in metabolic studies. We have found the left lateral segment of the liver to be an ideal site for biopsy for hepatocyte isolation. One distinct advantage of specimens obtained from this location is that hepatic capsule surrounds all sides of the biopsy except for the one cut surface. This optimizes the flow of perfusate throughout the specimen. We have utilized a lower flow rate and a longer period of perfusion compared with that used by Strom et al. (15).

The relationship between protein synthetic rates by freshly isolated hepatocytes as in our techniques and by the intact liver in vivo has been examined in several studies in animal models. In a comparison of hepatic protein synthesis in vivo using a flooding dose of tracer amino acid in a rat sarcoma model with in vitro measurements using freshly isolated hepatocytes, increased protein synthesis has been shown using both methods (20). However, the degree of stimulation seen was greater in the in vitro assay than in the in vivo method. Fornander et al. (21) showed a close correlation between in vivo protein synthesis using the flooding dose methods and in vitro liver slice method in an animal model of liver ischemia.

We have demonstrated that protein synthesis in hepatocytes isolated from cancer patients is higher than that from patients with benign disease with similar nutritional status and body weight loss. This same relationship was found for two different types of gastrointestinal malignancies: gastric and colorectal adenocarcinoma or lymphoma. It has not been determined from the present study what rates of hepatic protein synthesis would be obtained in patients with cancers outside the gastrointestinal tract.

Several studies have examined the role of liver protein synthesis in mice or rats with an implanted tumor. In general, these animal studies have shown increases in hepatic protein synthesis in malignancy where the animals have lost minimal actual weight (carcass weight) (7-10). It has been shown that techniques for measuring the rate of protein synthesis in vivo in a rapidly turning over tissue such as the liver must minimize the problem of assessing the correct precursor amino acid pool specific radioactivity and possible reutilization of label during the experiment (22). McNurlan and Garlick developed a technique for minimizing these problems by using a flooding dose of labeled amino acid precursor and by measuring the specific radioactivity of the precursor pool of free amino acid. Pain et al. (7), using this method in a mouse ascites tumor model, showed an increase in fractional rates of liver protein synthesis in comparison with pair-fed control animals. However, Emery et al. (8), using the same flooding dose amino acid technique, found a reduction in liver protein synthesis in mice with an implanted hypernephroma. It is interesting to note that in this model the tumor-bearing mice lost $20 \%$ of their body weight. These authors found that normal mice fasted for several days had a fall in protein synthesis in liver as severe as that observed in the tumor-bearing mice. Warren et al. (9), using isolated hepatocytes exposed to a high concentration of precursor amino acid, found an increase in total hepatocyte protein synthesis rates from rats bearing an implanted methylcholanthrene-induced sarcoma. In this study, the carcass weight (body weight minus tumor weight) for the tumor-bearing rats was $<5 \%$ lower than the carcass weight of the pair-fed control rats. In general in these animal studies, increases in liver protein synthesis have been demonstrated in malignancy where actual carcass weight is minimally decreased. We obtained similar results in our human hepatocyte studies.

Rates of human liver protein synthesis were examined using a liver slice technique by Lundholm et al. (11). Liver slices, of thickness $0.4 \mathrm{~mm}$, were made from specimens obtained from patients. Incorporation of leucine was measured using a high concentration of amino acids. These authors found an increased rate of protein synthesis in cancer patients compared with healthy control subjects. No mention was made in this study of nutritional status, body weight loss, or stage of tumor in these patients. Using the same liver slice technique, they found also an increased liver protein synthesis in mice bearing an implanted sarcoma.

We found a relationship between hepatocyte protein synthesis and percent body weight loss. Patients with $>5 \%$ body weight loss had reduced liver protein synthesis. Studies in rat have shown depression of hepatic protein synthesis (as a percent of the protein pool synthesized per day) both in starvation and in protein deprivation when an appropriately large dose tracer method is used (22-24).

We found elevated rates of hepatocyte protein synthesis in patients with colorectal carcinoma with liver metastases compared with those without liver metastases. Carmichael et al. (2), measured whole-body protein kinetics in patients with colorectal carcinoma using isotopic leucine tracer techniques. These authors found increased rates of whole-body protein turnover, synthesis, and breakdown in patients with Dukes D 
colorectal carcinoma (distant metastases, generally to the liver). For our study, the increased rates of hepatocyte protein synthesis in patients with metastatic liver disease may perhaps be related to the volume of tumor burden or perhaps to the quantity of normal liver tissue that remains for synthesizing protein.

To investigate possible qualitative changes in specific proteins being made by the liver in cancer and in differing nutritional states we examined levels of the acute-phase protein, CRP, in the sera from the patients we studied. Acute-phase proteins are increased in response to many forms of tissue injury, inflammation, infection, and cancer $(25,26)$. We found the highest CRP levels in patients with colorectal cancer metastatic to the liver and these levels were higher than those found in patients with colorectal cancer without hepatic metastases. The higher levels of protein synthesis in hepatocytes from patients with hepatic metastases from colorectal primary carcinoma may reflect, in part, higher rates of synthesis of acute-phase proteins such as CRP.

Alterations in levels of several hormones have been demonstrated in the settings of both malignancy and malnutrition (1-6). In samples obtained from patients at the onset of anesthesia after an overnight fast, we found no significant differences in either serum insulin or plasma glucagon levels that reflected changes we saw in hepatic protein synthesis. Insulin is known to stimulate hepatic protein synthesis (27), but serum insulin levels in rats with tumors have not been uniformly consistent $(1,9,27)$. Glucagon stimulates autophagic degradation of liver protein, particularly by affecting the intracellular amino acid supply (28). However, glucagon has been shown to inhibit protein synthesis in liver in rat studies (29). Perhaps a more likely possibility is stimulation of hepatic protein synthesis by glucocorticoids; cortisol has well-established effects on protein synthesis in liver (30). Increased cortisol levels have been observed in tumor-bearing humans compared with patients with benign surgical diseases (31). We found that patients with malignancies had higher plasma cortisol levels than those with benign disease.

Recently attention has been focused on products of activated macrophages producing metabolic alterations in chronic disease states (32-34). Tumor necrosis factor (TNF) has been shown to stimulate certain hepatic proteins and spontaneous elaboration of TNF by peripheral blood monocytes isolated from cancer patients has recently been demonstrated (35), indicating that endogenous TNF production may occur as part of the host's response to cancer. Other factors known to stimulate hepatic protein synthesis include interleukin-1 and hepatocyte-stimulating factors $(36,37)$. None of these mediators has been measured in the sera of patients with cachexia of chronic illness (34) or of cancer (38), and therefore their relative contributions to the metabolic disturbances of cancer cachexia remain a matter of speculation. Further work is in progress to elucidate the role of these hormones or other factors in mediating the effects of malignancy and malnutrition on host protein metabolism.

This study has shown alterations in hepatic protein synthesis in malignancy in man. However, the extent of cachexia (i.e., body weight loss) is an important variable. Patients with gastrointestinal malignancies who have not lost weight have increased hepatic protein synthesis rates compared with benign disease patients. The presence of a tumor may stimulate host hepatic protein metabolism at this stage. However, when nutrient intake decreases, a significant loss of body weight occurs and the patient becomes cachectic. Hepatic protein synthesis rates fall to low levels. Further investigation in hepatic protein metabolism may yield data on the optimal timing and regimens of nutritional support useful in the management of the cachectic cancer patient.

\section{Acknowledgments}

Grateful acknowledgment is extended to Martha Uhl, Mark Slattery, and Paul Leo for expert technical assistance. Patients studied under this protocol were cared for by the attending surgeons and fellows of the Gastric and Mixed Tumor and Colorectal Services at Memorial Sloan-Kettering Cancer Center.

This work was supported by National Institutes of Health grant CA-38858 and Training Grant CA-09501.

\section{References}

1. Jeevanandam, M., G. D. Horowitz, S. F. Lowry, and M. F. Brennan. 1984. Cancer cachexia and protein metabolism. Lancet. i: $1423-1426$.

2. Carmichael, M. J., M. B. Clague, M. J. Keir, and I. D. A. Johnston. 1980. Whole body protein turnover, synthesis, and breakdown in patients with colorectal carcinoma. Br. J. Surg. 67:736-739.

3. Glass, R. E., E. B. Fern, and P. J. Garlick. 1983. Whole body protein turnover before and after resection of colorectal tumors. Clin. Sci. (Lond.). 64:101-108.

4. Norton, J. A., T. P. Stein, and M. F. Brennan. 1981. Whole-body protein synthesis and turnover in normal man and malnourished patients with and without known cancer. Ann. Surg. 194:123-128.

5. Heber, D., R. T. Chlebowski, P. E. Ghibashi, J. N. Herrold, and J. B. Block. 1982. Abnormalities in glucose and protein metabolism in noncachectic lung cancer patients. Cancer Res. 42:4815-4819.

6. Burt, M. E., T. P. Stein, and M. F. Brennan. 1983. A controlled randomized trial evaluating the effects of enteral and parenteral nutrition on protein metabolism in cancer-bearing man. J. Surg. Res. 34:303-314.

7. Pain, V. M., D. P. Randall, and P. J. Garlick. 1984. Protein synthesis in liver and skeletal muscle of mice bearing an ascites tumor. Cancer Res. 44:1054-1057.

8. Emery, P. W., C. Lovell, and M. J. Rennie. 1984. Protein synthesis measured in vivo in muscle and liver of cachectic tumor-bearing mice. Cancer Res. 44:2779-2784.

9. Warren, R. S., M. Jeevanandam, and M. F. Brennan. 1985. Protein synthesis in the tumor-influenced hepatocyte. Surgery (St. Louis). 98:275-281.

10. Kawamura, I., L. L. Moldawer, R. A. Keenan, G. Batist, A. Bothe, B. R. Bistrian, and G. L. Blackburn. 1982. Altered amino acid kinetics in rats with progressive tumor growth. Cancer Res. 42:824829.

11. Lundholm, K., S. Edstrom, L. Ekman, I. Karlberg, A. C. Bylund, and T. Schersten. 1978. A comparative study of the influence of malignant tumor on host metabolism in mice and man. Cancer (Phila.). 42:453-461.

12. Berry, M. N., D. S. Friend. 1969. High yield preparation of isolated rat liver parenchymal cells. J. Cell Biol. 43:506-520.

13. Seglen, P. O. 1976. Preparation of isolated rat liver cells. Methods Cell Biol. 13:29-83.

14. Bourel, M., Y. Le Guilly, P. Lenoir, B. Ferrano, and H. Febvre. 1968. Culture de fois humain adulte. Comptes Rendus Soc. Biol. 162:979-983.

15. Strom, S. C., R. L. Jirtle, R. S. Jones, D. C. Novicki, M. R. Rosenberg, A. Novotny, G. Irons, J. R. McLain, and G. Michalopoulos. 1982. Isolation, culture, and transplantation of human hepatocytes. J. Natl. Cancer Inst. 68:771-778.

16. Mitchell, D. B., K. S. Santone, and D. Acosta. 1980. Evaluation of cytotoxicity in cultured cells by enzyme leakage. J. Tissue Culture Methods. 6:113-116. 
17. Seglen, P. O., A. E. Solheim, B. Grinde, P. B. Gordon, P. E. Schwarze, R. Gjessing, and A. Poli. 1980. Amino acid control of protein synthesis and degradation in isolated rat hepatocytes. Ann. N.Y. Acad. Sci. 349:1-17.

18. Snedecor, G. W., and W. G. Cochran. 1971. Statistical Methods. Iowa State University Press, Ames, IA.

19. Rennie, M. J., R. H. T. Edwards, D. Halliday, D. E. Matthews, S. L. Wolman, and D. J. Millward. 1982. Muscle protein synthesis measured by stable isotope techniques in man: the effects of feeding and fasting. Clin. Sci. (Lond.). 63:519-523.

20. Warren, R. S., M. Jeevanandam, and M. F. Brennan. 1987. Comparison of hepatic protein synthesis in vivo vs. in vitro in the tumor bearing rat. J. Surg. Res. 42:43-50.

21. Fornander, J., J. Bergmark, R. Jagenburg, and P. O. Hasselgren. 1985. Evaluation of an in vitro method for the study of hepatic protein synthesis in liver ischemia. Eur. Surg. Res. 17:91-100.

22. McNurlan, M. A., and P. J. Garlick. 1981. Protein synthesis in liver and small intestine in protein deprivation and diabetes. Am. J. Physiol. 241:E238-E245.

23. McNurlan, M. A., A. M. Tomkins, and P. J. Garlick. 1979. The effect of starvation on the rate of protein synthesis in rat liver and small intestine. Biochem. J. 178:373-379.

24. Garlick, P. J., P. J. Millward, W. P. T. James, and J. C. Waterlow. 1975. The effect of protein deprivation and starvation on the rate of protein synthesis in tissues of the rat. Biochim. Biophys. Acta. 414:71-84.

25. Sganga, G., J. H. Siegel, G. Brown, G. Coleman, C. E. Wiles, H. Belzberg, H. Wedel, and R. Placko. 1985. Reprioritization of hepatic plasma protein release in trauma and sepsis. Arch. Surg. 120:187-199.

26. Cooper, E. H., and J. Stone. 1979. Acute phase reactant proteins in cancer. Adv. Cancer Res. 30:1-44.

27. Goodlad, G. A. J., A. J. H. Mitchell, L. McPhail, and G. M. Clark. 1975. Serum insulin and somatomedin levels in the tumorbearing rat. Eur. J. Cancer. 11:733-737.
28. Schworer, C. M., and G. E. Mortimore. 1979. Glucagon-induced autophagy and proteolysis in rat lever: mediation by selective deprivation of intracellular amino acids. Proc. Natl. Acad. Sci. USA. 76:3169-3173.

29. Ayuso-Parrilla, M. S., A. Martin-Requero, J. Perez-Diaz, and R. Parrilla. 1976. Role of glucagon on the control of hepatic protein synthesis and degradation in the rat in vivo. J. Biol. Chem. 251:77857790.

30. Odera, B. R., P. C. Bates, and D. J. Milward. 1983. Time course of the effect of catabolic losses of corticosterone on protein turnover in rat skeletal muscle and liver. Biochem. J. 214:617-627.

31. Schaur, R. J., H. Fellier, H. Gleispach, E. Fink, and C. Kronberger. 1979. Tumor host relations. I. Increased plasma cortisol in tumor-bearing humans compared with patients with benign surgical diseases. J. Cancer Res. Clin. Oncol. 93:281-285.

32. Old, L. J. 1985. Tumor necrosis factor. Science (Wash. DC). 230:630-632.

33. Beutler, B., and A. Cerami. 1986. Cachectin and tumor necrosis factor as two sides of the same biological coin. Nature (Lond.). 320:584-588.

34. Beutler, B., and A. Cerami. 1987. Cachectin: more than tumor necrosis factor. N. Engl. J. Med. 316:379-385.

35. Aderka, D. N., S. Fisher, Y. Levo, H. Holtmann, T. Hahn, and D. Wallach. 1985. Cachectin/tumor necrosis factor production by cancer patients. Lancet. ii:1196.

36. Dinarello, C. A. 1984. Interleukin-1 and the pathogenesis of the acute phase response. N. Engl. J. Med. 311:1413-1418.

37. Baumann, H., R. E. Hill, D. N. Sauder, and G. P. Jahreis. 1986. Regulation of major acute-phase plasma proteins by hepatocyte-stimulating factors of human squamous carcinoma cells. J. Cell Biol. 102:370-383.

38. Scuderi, P., K. S. Lam, K. J. Ryan, E. Petersen, K. E. Sterling, P. R. Finley, C. G. Ray, D. J. Slymen, and S. E. Salmon. 1986. Raised serum levels of tumour necrosis factor in parasite infections. Lancet. ii: $1364-1365$. 